\title{
Strategy for DNA extraction and detection from insect pests in stored home grain samples
}

\author{
RESEARCH \\ Ibrahim Abbasi ${ }^{1, *}$, Lamia Halaseh², Hisham M. Darwish ${ }^{2,3}$, and Imad Matouk \\ ${ }^{1}$ Department of Biological Sciences, Al-Quds University, Jerusalem, Palestine. \\ ${ }^{2}$ Medical Research Center, Faculty of Medicine, Al-Quds University, Jerusalem, Palestine. \\ ${ }^{3}$ Faculty of Allied Medical Sciences, Arab American University, Palestine.
}

\begin{abstract}
A B S T R A C T
Stored grains are subjected to infestations with more than 60 species of insects, that responsible for millions of dollars loss and cause several health problems including allergies and gastrointestinal disorders. Traditional detection techniques are laborious, expensive and not sensitive to detect insect contamination at the egg and larvae stages. Therefore, alternative methods are needed for rapid and sensitive detection. One obvious approach is to develop a molecular approach utilizing genetic information of the potential insect species that infest grains for amplification of specific target gene fragment utilizing polymerase chain reaction [PCR]. In the present study, a number of known infested grain samples were used in standardizing a method to isolate larvae and adult insects that were based on centrifugation washing method and a filtration washing method. The isolated insects were subjected to DNA extraction and PCR amplification of defined regions of cytochrome oxidase I (COI) gene followed by sequencing to identify the different pest species. For PCR amplification new primers were designed and for this purpose the obtained $\mathrm{COI}$ sequences from different insects were aligned to design two sets of primers (named: COI-PCR4 and COI-PCR5) specific for the indicated insect mitochondrial COI gene. The designed primers were tested for their specificity and sensitivity. The suitability of PCR primers and DNA extraction methods were evaluated on eleven samples of commercial grains utilizing each primer set with the two extraction methods.
\end{abstract}

Keywords: Insect pests, grain, DNA extraction

\section{Introduction}

Grains are considered as the world's primary stable food and its seasonal harvesting obligates storage for different time periods either for short-term or long-term periods (Proctor, 1994; Rajashekar et al., 2010). During storage, grains are exposed to damage by microorganisms, mice and insect pests, which destroy about 10-

\footnotetext{
* Correspondance:

Department of Biological Sciences, Al-Quds University, Abu Dies, Palestine.

P.O.Box P.O.Box 20002 Jerusalem, Palestine.

Tel:0972-2-2799753. Fax:0972-2-2796960.

E-mail: iabbasi@staff.alquds.edu

(c) copy rights 2021 : All materials in this article is protected, permission requests should be addressed Al-Quds University. www.alquds.edu
}

$20 \%$ of agricultural products annually (Dragisic Maksimovic et al., 2015; Rajashekar et al., 2010) (Holst et al., 2000). Improper maintenance of storage temperature and humidity leads to insect development, which then leads to biological and chemical damage (Chattha et al., 2015), For these reasons it is important to examine grains periodically for early detection of insects in order to minimize grain loss.

Over 60 species of insects can infest stored grains (Jian, 2019). Beetles (order Coleoptera), moths (order Lepidoptera) and mites (class Arachnida) are the most common species that live in human food grains (Aspaly et al., 2007) (Collins, 2012; Garcia-Cela et al., 2019; Waongo et al., 2019). The principle pests stages that cause 
damage are adult and larval stages of beetles and the larval stage of moths (Aspaly et al., 2007; Collins, 2012) (Abd El-Aziz, 2011; Hafiz, 1983). The presence of insect pests in grains causes quantitative loss due to direct feeding of insects which reduces grain weight, nutritional value and qualitative loss by contaminating the grains with insect excreta, pupal cocoons, dead bodies and odors (Collins, 2012). Many health problems are associated with insect infestations such as allergies, diarrhea and others (Arbogast et al., 2000; Athanassiou et al., 2017). Some of these pests act as vectors for aflatoxin producing fungi (Hell et al., 2000). Other insects have been involved in the transmission of pathogenic bacteria such as salmonella and Enterococcus spp. (Crumrine et al., 1971). Animals also may be affected if their feed were contaminated with insects and mites (Channaiah et al., 2010; Hell et al., 2000).

Visual inspection, sampling and sieving are widely used for insect detection in grains (Aspaly et al., 2007). Other methods were developed to detect hidden infestations including staining of kernels to detect eggs, density separation (Shi et al., 2016), x-ray micro-tomography (Toews et al., 2006), acoustical sensors technique (Mankin et al., 2010), near infrared spectroscopy (PerezMendoza et al., 2005), Enzyme-Linked Immunosorbent Assay (ELISA) (Dunn et al., 2008) and uric acid analysis (Wehling et al., 1984). The accuracy of these methods depends on insect species, their developmental stage and grain type (Abels and Ludescher, 2003; Dasmahapatra, 2010).

Molecular techniques were widely used to detect viruses, bacteria, fungi and insect pests with significant rapidity, reliability and allowed for large-scale analysis of multiple samples (Nowaczyk et al., 2009). This approach allows the detection of primary pests inside grain kernels after oviposition and during the early larval stages based on DNA barcoding using short DNA sequences from known region of the genome as a reference sequence for species identification (Abels and Ludescher, 2003; Dasmahapatra, 2010). DNA barcoding emerged as a rapid method for insect detection and identification by comparing unknown sequences against DNA barcodes for known species via distance-based tree construction or alignment searching (e.g., BLAST) (Min and Hickey, 2007; Virgilio et al., 2012). The standard sequence used was mitochondrial cytochrome c oxidase subunits $\mathrm{COI}$ and COll, cytochrome b or ribosomal DNA (Dasmahapatra, 2010; Virgilio et al., 2012).

The main focus of this study is to develop a reliable and specific molecular test for the detection of insect pests in home stored grains, standardization of suitable treatment for grains before DNA extraction and optimization of a convenient and efficient DNA extraction method suitable for insects found in plant seed.

\section{Materials and Methods}

Samples

A total of 11 grain samples including: corn, groat, lentils, rice, wheat, corn flakes, chickpeas, cumin, sesame, barely and animal feed were collected from local wholesale grocery stores. Samples were chosen randomly from sacks that comprised of 500 grams of large grains $(<0.5 \mathrm{~cm})$ and 250 grams of fine grains $(>0.5 \mathrm{~cm})$. Positive control samples were consist of rice, flour and barely samples that were heavily contaminated with fully developed larvae and adult insect pests. Insects' larvae and adult stages collected from infested flour, rice, and barely were isolated for DNA extraction and species identification.

\section{Sample preparation for DNA extraction}

All samples were processed using two procedures. 1-Centrifugation washing method: where 10 grams of grains were transferred to $50 \mathrm{ml}$ sterile plastic tubes containing $20 \mathrm{ml}$ distilled water followed by mixing for 2 minutes, then $10 \mathrm{ml}$ of the turbid water were transferred into empty $50 \mathrm{ml}$ plastic tube and centrifuged for $10 \mathrm{~min}$ at $4000 \mathrm{rpm}$. The supernatant was discarded and the pellet was collected for DNA extraction. 2-Filtration washing method: 50 grams of grains were transferred to sterile $100-200 \mathrm{ml}$ glass beakers (according to grain size) containing $70 \mathrm{ml}$ sterile distilled water, mixed for $2 \mathrm{~min}$, then $40 \mathrm{ml}$ of the turbid water were drawn and filtrated through $47 \mathrm{~mm}$ diameter and $8 \mu \mathrm{m}$ pore 
size nitrocellulose membrane filters (Whatman Inc, Piscatway, NJ) using a vacuum filtration system. The membrane filters were left at room temperature to dry, punched and 4 small disks $(0.5 \mathrm{~cm}$ diameter) were taken for DNA extraction.

\section{DNA extraction}

The pellet or the filter discs were incubated in $1.5 \mathrm{ml}$ tubes with $200 \mu \mathrm{l}$ lysis buffer $(50 \mathrm{mM}$ $\mathrm{NaCl}, 10 \mathrm{mM}$ EDTA, $50 \mathrm{mM}$ Tris-HCl pH 7.4, 1\% triton hours. Equal volume of TE-saturated phenol $(\mathrm{pH} 8)$ was added to the aqueous solution, vortexed for few seconds and then centrifuged for 2 minutes at 14,000 rpm. The upper aqueous layer was transferred to new tube and DNA was precipitated by $0.2 \mathrm{M} \mathrm{NaCl}$ and 2.5 volumes of $100 \%$ cold ethanol. The mixture was incubated overnight at $-200 \mathrm{C}$ and centrifuged at 14,000 rpm for 10 minutes. The DNA pellet was left to dry then it was suspended in 100 $\mu \mathrm{l}$ of sterile double distilled water and stored at $-20^{\circ} \mathrm{C}$ until further use.

\section{Primers Design}

At the beginning; three different $P C R$ systems (COI-PCR1, COI-PCR2, and COI-PCR3 were designed that amplify cytochrome oxidase I (COI) gene of Diptera insects (Table 1), these PCR systems were used to amplify $\mathrm{COI}$ gene from extracted DNA of larvae and adult insects isolated from rice, flour and barely infested samples. The amplification products were subjected for DNA sequence analysis for pests species identification using BLAST generated comparison with their original $\mathrm{CO}$ gene DNA sequences. Based on new COl gene DNA sequence of the identified pests, new primers were designed from regions of highly conserved sequences of $\mathrm{CO}$ / with the assumption to amplify $\mathrm{COI}$ gene from many other pest species (Table 1).

\section{Polymerase Chain Reaction (PCR)}

The amplification reaction was carried in 25 $\mu \mathrm{l}$ final volume using $2 \mathrm{x}$ concentrated green-Taq DNA polymerase (Thermo-Fisher, USA), 15 pmoles of each primer (reverse and direct), $2 \mu \mathrm{l}$ of the original DNA extract or $5 \mu$ of the 1:10 diluted sample. The amplification protocol was run as follows: 5 min at $95^{\circ} \mathrm{C}$ followed by 35 cycles of 30 seconds at $95^{\circ} \mathrm{C}, 30$ seconds at $50^{\circ} \mathrm{C}, 1 \mathrm{~min}$ at 72 ${ }^{\circ} \mathrm{C}$, and a final elongation step at $72{ }^{\circ} \mathrm{C}$ for $10 \mathrm{~min}$. The amplified DNA fragments were resolved on $1.5 \%$ agarose gel in TAE buffer ( $40 \mathrm{mM}$ Tris, $20 \mathrm{mM}$ acetic acid, 1mM EDTA).

\section{DNA Purification and DNA sequencing}

PCR amplified DNA fragments were purified by PCR purification kit (Qiagene, Germany) according to the manufacturer instructions. The purified products were sequenced based on dye terminator method, using an automated DNA Sequencer machine (AB477).

Table1:DNA sequence information of the used primers

\begin{tabular}{|c|c|c|c|c|}
\hline PCR system & Primer Direction & Primer sequence (5'-3') & Amplicon size(bp) & $\operatorname{Tm}\left(c^{\circ}\right)$ \\
\hline \multirow[t]{2}{*}{ COI-PCR1 } & Forward & TCATAAAGATATTGGAACTTTATAC & 750 & 53.1 \\
\hline & Reverse & GATGTCCAAAAAATCAAAATAAAT & & 50.7 \\
\hline \multirow[t]{2}{*}{ COI-PCR2 } & Forward & GGAACTGGGTGAACAGTTTATCCCCC & 350 & 66.4 \\
\hline & Reverse & ATGTTGATAAAGAATAGGATCTCCTCC & & 60.4 \\
\hline \multirow[t]{2}{*}{ COI-PCR3 } & Forward & AATAATATAAGATTTTGACTTCTTCC & 350 & 52.8 \\
\hline & Reverse & TATAGTAATAGCTCCAGCTAAAACTGG & & 52.8 \\
\hline \multirow[t]{2}{*}{ COI-PCR4 } & Forward & ATTGGAGGATTCGGAAATTGA & 456 & 52.0 \\
\hline & Reverse & ССTCСTGCTGGATCAAAAAA & & 55.5 \\
\hline
\end{tabular}




\section{DNA Quantification}

DNA positive controls were quantified using a NanoDrop instrument (Thermo Fisher scientific Inc, Waltham, Massachusetts, USA). Most of the positive control DNA samples were in the range between 50 to $300 \mathrm{ng} / \mu \mathrm{l}$ while the DNA extracted from grain samples ranged between $400 \mathrm{ng}$ to $2 \mu \mathrm{g} /$ $\mu$ l.

\section{Results}

\section{Preliminary screening of insect grain pests}

DNA was extracted from isolated adult insects infesting barely and flour samples (Figure 1), followed by PCR amplification using the three Diptera based PCR systems (COI-PCR1, COI-PCR2, and COI-PCR3).

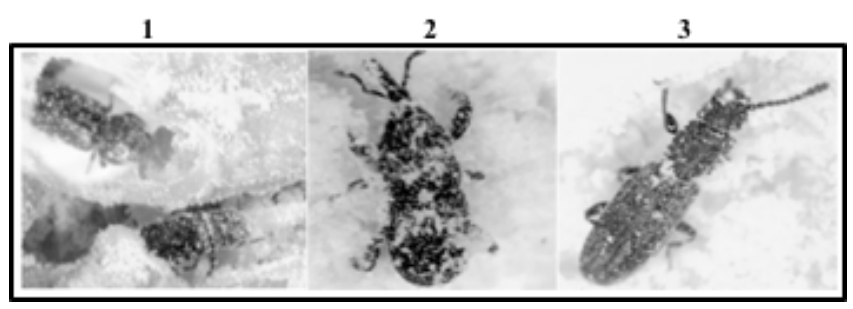

Figure 1: Different insect pest isolated from barely and flour infested samples which were identified according to their COI DNA sequence: (1) Barely: lesser grain borer (2) flour: granary weevil (3) flour sawtoothed grain beetle.

A successful PCR amplification was achieved by both COI-PCR1 and COI-PCR2 but not with the third PCR system (COI-PCR3) (Figure 2).

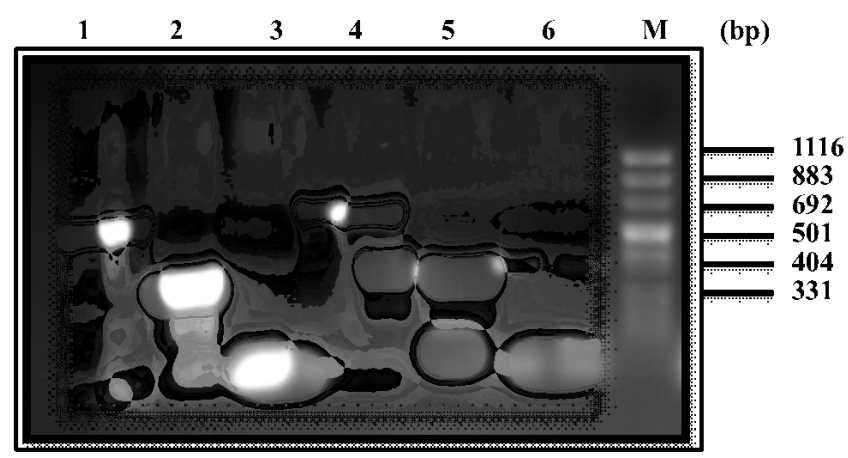

Figure 2: Agarose gel electrophoresis analysis of PCR amplified product of insect's DNA extracted from infested rice sample. 1 and 4: COI-PCR1, 2 and 5: COIPCR2, 3 and 6: COI-PCR3. (M) Size marker.

DNA fragment about 700bp was amplified by COI-PCR1, and a fragment about 350bp was amplified by COI-PCR2. The amplified COI-PCR1 and COI-PCR2 DNA fragments from different unknown pests that were found in infested grains were sequenced. The sequence information was used to design more specific primers that are suitable to amplify $\mathrm{COI}$ gene from rice and grain pests (as described below).

\section{Designing new specific primers}

Based on the newly acquired COI DNA sequence information it was possible to identify pest type found in infested grain using BLAST sequence comparison. Table 2 shows a list of the major types of the identified pests and the similarity percentage to the obtained sequences. The DNA sequences of $\mathrm{COl}$ gene for the identified pests in table 2 were aligned using ClastalW2 software. The main purpose of this alignment is to identify a potential shared sequences for new primers that have the ability for a wider range of COI DNA gene amplification from many other pests species; and also a longer $\mathrm{CO}$ amplification that enables species identification after DNA sequence analysis. New direct and reverse primers that were used in PCR systems named: COI-PCR4 and COI-PCR5 were designed, these PCR systems amplify DNA segments of 456bp and $370 b p$ respectively.

Table 2: Insect pest identified according to BLAST generated comparison

\begin{tabular}{|c|c|c|c|}
\hline $\begin{array}{l}\text { Pest scientific } \\
\text { name }\end{array}$ & $\begin{array}{l}\text { Pest common } \\
\text { name }\end{array}$ & $\begin{array}{c}\text { Accession } \\
\text { number }\end{array}$ & $\begin{array}{c}\text { Matching } \\
\%\end{array}$ \\
\hline $\begin{array}{l}\text { Plodia } \\
\text { interpunctella }\end{array}$ & $\begin{array}{l}\text { Indian meal } \\
\text { moth }\end{array}$ & GU096541.1 & $99 \%$ \\
\hline Oryzaephilus spp. & Grain beetle & KC407725.1 & $85 \%$ \\
\hline Sitophilus spp. & Weevil & AY131101.1 & $76 \%$ \\
\hline Rhyzopertha spp. & Grain beetle & KC407718.1 & $79 \%$ \\
\hline
\end{tabular}

\section{Specificity analysis}

The newly designed PCR systems (COI-PCR4 and COI-PCR5) were tested for their specificity. They did not amplify DNA extracted from insect free grains, plant leaves, and human DNA, even if 100 ng of DNA was used from each type of DNA (data not shown). 


\section{Sensitivity analysis}

Serial dilutions ranged from $10 \mathrm{ng}$ to $1 \mathrm{pg}$ of DNA extracted from beetles were used to test the sensitivity of COI-PCR4 and COI-PCR5. It was clearly seen that COI-PCR4 is more sensitive than COI-PCR5; since it could amplify 1pg of the pests genomic DNA while the sensitivity of COI-PCR5 reached only to 10pg of DNA (Figure 3).

A

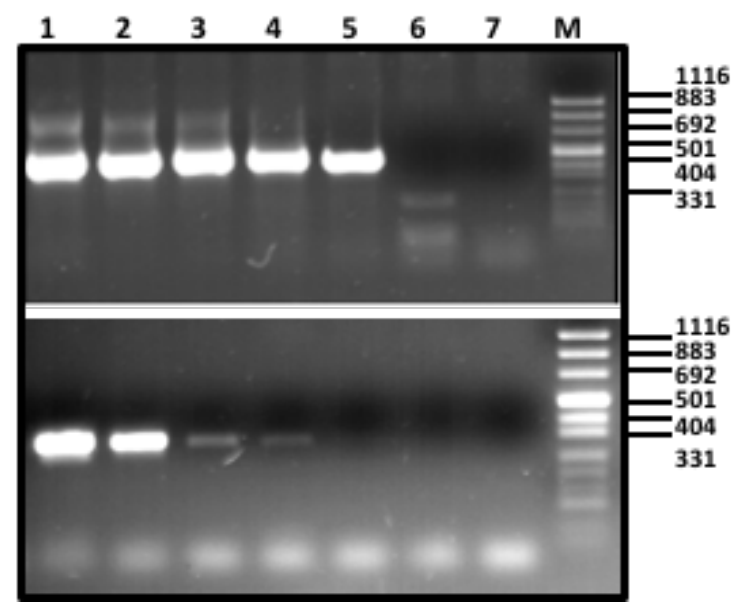

Figure 3: Sensitivity test of COI-PCR4 (A) and COI-PCR5 (B) targeting different concentration of beetle's pure genomic DNA isolated from barely. lane 1- 10ng, lane 2-1ng, lane 3- 0.1ng, lane 4- 0.01ng, lane 5- 1pg, lane 6- 0.1pg, lane 7-Negative control, M: DNA size marker

\section{Detection of pests in commercial collected grains}

The two newly developed PCR systems (COIPCR4 and COI-PCR5) were used to amplify pests' COI gene from 11 tested samples; after DNA extraction by filtration or centrifugation methods. PCR was performed with the extracted DNA and with DNA diluted 1:10. The results of the positive amplifications using both PCR systems with DNA extracted by the two indicated methods are summarized in table 3. COI-PCR4 system proved to be more efficient than COI-PCR5 in COI gene amplification from infected samples. Using this PCR system, it was possible to detect the presence of pests DNA in all 11 tested samples extracted by filtration washing method and after diluting 1:10. While using DNA extracted by the centrifugation method, it detects 10 out of 11 infected samples (Table 3, Figure 4).

The amplified COI fragment using COI-PCR4 system that target DNA samples from:
Table 3: Results of COI DNA amplification using COIPCR4 and COI-PCR5 combined with centrifugation washing or filtration washing methods.

\begin{tabular}{lccc}
\hline $\begin{array}{l}\text { Extraction } \\
\text { method }\end{array}$ & PCR system & $\begin{array}{c}\text { Total positives } \\
\text { original sample/ } \\
\text { total }\end{array}$ & $\begin{array}{c}\text { Total positives } \\
\text { diluted (1:10)/ } \\
\text { total }\end{array}$ \\
\hline Centrifugation & COI-PCR4 & $6 / 11$ & $10 / 11$ \\
& COI-PCR5 & $4 / 11$ & $7 / 11$ \\
Filtration & COI-PCR4 & $9 / 11$ & $11 / 11$ \\
& COI-PCR5 & $4 / 11$ & $5 / 11$ \\
\hline
\end{tabular}

\section{Centrifugation washine method}

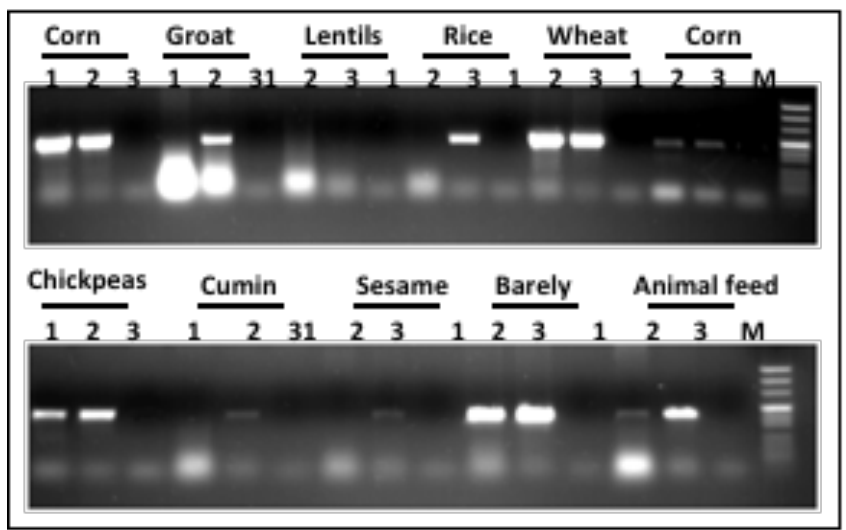

Filtration washing method

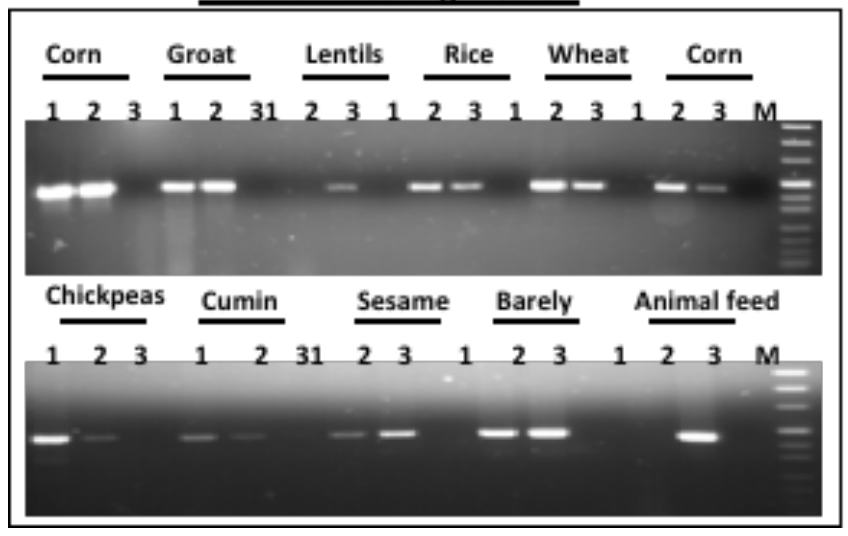

Figure 4: Agarose gel electrophoresis analysis of amplicons produced by COI-PCR4 primer system targeting DNA extracted from different types of grain samples by the centrifugation washing method (above) and filtration washing method (below). 11 samples were tested using three PCR reactions: 1- undiluted DNA, 2- diluted 1:10, 3- No DNA control. M: DNA size marker (bp).

corn, chickpeas, animal feed, rice and wheat extracted by centrifugation methodwere sequenced for species identification, the obtained 
sequences were identified according to BLAST generated comparison as shown in table 4.

Table 4: insects identified according to BLAST generated comparison (amplification using COI-PCR4)

\begin{tabular}{lccc}
\hline Pest scientific name & $\begin{array}{c}\text { Source } \\
\text { (sample) }\end{array}$ & $\begin{array}{c}\text { Accession } \\
\text { number }\end{array}$ & $\begin{array}{c}\text { Matching } \\
\%\end{array}$ \\
\hline $\begin{array}{l}\text { Rhyzopertha spp. } \\
\text { Rhyzopertha spp. }\end{array}$ & Corn & KC407718.1 & $89 \%$ \\
$\begin{array}{l}\text { Camea spp. } \\
\text { (lepidoptera spp.) }\end{array}$ & KCC407718.1 & $74 \%$ \\
$\begin{array}{l}\text { Rhyzopertha dominica } \\
\text { Rhyzopertha dominica }\end{array}$ & HM905018.1 & $84 \%$ \\
& Wheat & KC407718.1 & $99 \%$ \\
\hline
\end{tabular}

\section{Discussion}

During shipping or storage periods grains are subjected to be infested by insect pests and mite, which cause economical losses by reducing grains quantity and quality. Hence, it is very important to adapt a sensitive method in order to detect insects at an early developmental stage or egg stage and implement control measures for the elimination of these insects and thereby reducing the loss of grains (Ngom et al., 2020). Insects can be found in many food components that if stored in cool dry conditions can slow further developmental stages that are hardly detected by the naked eye (Barrozo, 2019). In addition, many edible products are included in processed food as grind and milled materials infested with many types of insects that are hard to identify based on macro- or microscopic examinations (Abels and Ludescher, 2003; Hubert et al., 2018). Therefore, it is very important to develop a reliable sensitive diagnostic test that overcomes most classical insect detection methods even after processing. Consequently, detecting insects' genetic material provides a sensitive and specific examination tool for food and grain pests.

Previous studies using molecular approach dealt with one or two insect pests but lack the ability to detect several species of insects from different orders (Dasmahapatra, 2010). Our investigation focused on applying PCR amplification based on defined regions in the insects cytochrome oxidase I gene using general COI primers that are more specific for dipteral insects. Using this strategy, it was possible to detect and eventually identify different insects species in stored grains. DNA detection methods based on mitochondrial DNA is characterized by high sensitivity because of its many copies in the cell and approximately all mitochondrial genes sequences are known (Min and Hickey, 2007). The mitochondrial genes $\mathrm{COI}$ and COll subunits were used in standard molecular techniques to detect granary weevil in wheat flour (Ahrens et al., 2007). The DNA sequences of the amplified DNA fragments facilitated the design of more specific and sensitive amplification PCR systems for specific identification of insects in various grain samples.

Direct DNA extraction from grain samples by adding lyses buffer was not possible and several attempts were tried to overcome this problem, including the use of small sample size followed by short time incubation at high temperature for a quick extraction step. However, adapting this method for DNA extraction from plant or food materials for the purpose of insect examination was terminated since the small sample size can be misleading and many insect positive samples can be missed. These trials lead to the adaptation of two extraction procedures: 1- centrifugation washing and 2- filtration washing methods. Both protocols did not involve the addition of lyses buffer for long time in the presence of grain. This was achieved using a washing step with distilled water; and then collecting the wash water that contains particles; dust, eggs and fragments that were re-suspend in the lyses buffer. The filtration method relied on insect particles that will be returned on filter membrane with a pore size smaller than the smallest known pest egg (Wilson et al., 2003). Insect pest egg size ranges from 0.24-0.72 $\mathrm{mm}$ and the used membrane filter has a pore size of $8 \mu \mathrm{m}$. Another important complication was resolved after adopting these methods namely the dramatic reduction of plant DNA and proteins that may interfere in insects COI DNA amplification (Church et al., 2019).

All positive controls of insects DNA used in 
our study were extracted from whole insects or their larvae that were directly removed from infested samples. Although it was possible to use previously identified COI DNA sequences for designing specific primers, we decided to have direct COI DNA sequences from our collected samples to identify specific types of insects isolated from local home or stores of grain samples (Min and Hickey, 2007). The developed COI-PCR4 and COI-PCR5 proved to be insect specific and did not amplify plant or human genomic DNA. These two systems also proved to be very sensitive, since it was possible to amplify 1pg of insect DNA template reflecting the sensitivity limits of these two systems. This sensitivity is equivalent to the detection of one egg found in 10 grams of grain sample (Ahrens et al., 2007).

Using classical PCR amplification, it is not possible to have quantitative results based on a single reaction. A quantitative procedure is needed to determine the insect accepted threshold level in grains according to the Federal Grain Inspection Service (FGIS) in the United States, which determines the number of insects allowed in grains (Fang et al., 2002). The combination of COlPCR4 system and filtration system was sufficiently sensitive to detect even lower quantities than the allowed threshold level. Eventually, adapting these primers in a real-time quantitative PCR protocol would be even more sensitive for insect level detection.

The current developed molecular approach to detect insect pests in samples of stored grains were tested on eleven samples randomly collected from local stores. These samples were not purposely contaminated by insect pest for research purposes like previous studies (Hubert et al., 2018; Perez-Mendoza et al., 2005) but rather were processed as described using both centrifugation and filtration methods. The results based on using COI-PCR4 system in combination with centrifugation method shoed that ten of eleven collected grain samples were found to be positively infested. The results included positive amplification from corn, wheat, chickpeas, barely which gave very strong bands using the original and diluted samples, groat, rice and animal feed also gave strong bands for diluted samples only, lentils gave negative results whether using diluted or undiluted samples. The results indicated that using the filtration method for DNA extraction was more efficient and gave better results with the CO1-PCR4 system than the centrifugation method.

In conclusion, the data shown in this study represents a major step for the establishment of a rapid, sensitive and reliable molecular method for insect detection infested grains based on specific genetic marker information. Further work is needed to optimize the method for the specific identification of the various insects and develop a quantitative assay for the assessment the degree of contamination with the early developmental stages of insects for proper handling of contaminated grains. Furthermore, efforts will be directed to develop a multiplex test based on the present results for the detection of the vast majority of insects species known to infest grains. Eventually, this technique will hopefully open the way for the adoption of a national program to screen all imported and locally stored grains for periodic inspection to ensure the safety of grains for human consumption and prevents losses that can have a significant economical impact. Definitely, detection of insects contamination in grains at early stages will allow early interference to ensure the eradication of all contaminants utilizing effective and reliable methods that are used around the world for this purpose.

\section{References}

Abd El-Aziz, S.E., 2011. Control Strategies of Stored Product Pests. Journal of Entomology Volume: 8 101-122.

Abels, J.P., Ludescher, R.D., 2003. Native fluorescence from juvenile stages of common food storage insects. Journal of agricultural and food chemistry 51, 544-549.

Ahrens, D., Monaghan, M.T., Vogler, A.P., 2007. DNA-based taxonomy for associating adults and larvae in multi-species assemblages of chafers (Coleoptera: Scarabaeidae). Molecular phylogenetics and evolution 44, 436-449.

Arbogast, R.T., Kendra, P.E., Mankin, R.W., McGovern, J.E., 2000. Monitoring insect pests in retail stores by trapping and spatial analysis. Journal of economic entomology 93, 1531-1542. 
Aspaly, G., Stejskal, V., Pekar, S., Hubert, J., 2007. Temperaturedependent population growth of three species of stored product mites (Acari: Acaridida). Experimental \& applied acarology 42, 37-46.

Athanassiou, C.G., Kavallieratos, N.G., Campbell, J.F., 2017. Effect of the Presence of Live or Dead Insects on Subsequent Captures of Six Stored-Product Beetle Species: The Relative Species Matters. Journal of economic entomology 110, 770-775.

Barrozo, R.B., 2019. Food recognition in hematophagous insects. Current opinion in insect science $34,55-$ 60.

Channaiah, L.H., Subramanyam, B., Zurek, L., 2010. Survival of Enterococcus faecalis OG1RF:pCF10 in poultry and cattle feed: vector competence of the red flour beetle, Tribolium castaneum (Herbst). Journal of food protection 73, 568-573.

Chattha, S., Hasfalina, C., Mahadi, M., Mirani, B., Lee, T., 2015. Quality change in wheat grain during storage in a ferrocement bin. ARPN Journal of Agricultural and Biological Science 10, 11.

Church, S.H., Donoughe, S., de Medeiros, B.A.S., Extavour, C.G., 2019. A dataset of egg size and shape from more than 6,700 insect species. Scientific data 6, 104.

Collins, D.A., 2012. A review on the factors affecting mite growth in stored grain commodities. Experimental \& applied acarology 56, 191-208.

Crumrine, M.H., Foltz, V.D., Harris, J.O., 1971. Transmission of Salmonella montevideo in wheat by storedproduct insects. Applied microbiology 22, 578580.

Dasmahapatra, K.E., M. Hill, R. Hoffman, J. Mallet, J., 2010. Mitochondrial DNA barcoding detects some species that are real, and some that are not. Mol Ecol Resour 10, 264-273.

Dragisic Maksimovic, J., Poledica, M., Mutavdzic, D., Mojovic, M., Radivojevic, D., Milivojevic, J., 2015. Variation in nutritional quality and chemical composition of fresh strawberry fruit: combined effect of cultivar and storage. Plant foods for human nutrition 70, 77-84.

Dunn, J.A., Thind, B.B., Danks, C., Chambers, J., 2008. Rapid method for the detection of storage mites in cereals: feasibility of an ELISA based approach. Bulletin of entomological research 98, 207-213.

Fang, L., Subramanyam, B., Dolder, S., 2002. Persistence and efficacy of spinosad residues in farm stored wheat. Journal of economic entomology 95 , 1102-1109.

Garcia-Cela, E., Kiaitsi, E., Sulyok, M., Krska, R., Medina, A., Petit Damico, I., Magan, N., 2019. Influence of storage environment on maize grain: CO2 production, dry matter losses and aflatoxins contamination. Food additives \& contaminants. Part A, Chemistry, analysis, control, exposure \& risk assessment 36 , 175-185.

Hafiz, A., 1983. Losses incurred in stored food grains by insect pests- a review. Pakistan J. Agric. Res. 4, 12.

Hell, K., Cardwell, K.F., Setamou, M., Poehling, H., 2000. The influence of storage practices on aflatoxin contamination in maize in four agroecological zones of Benin, west Africa. Journal of stored products research 36, 365-382.

Holst, N., Meikle, W.G., Markham, R.H., 2000. Grain injury models for Prostephanus truncatus (Coleoptera: Bostrichidae) and Sitophilus zeamais (Coleoptera: Curculionidae) in rural maize stores in West Africa. Journal of economic entomology 93, 1338-1346.

Hubert, J., Stejskal, V., Athanassiou, C.C., Throne, J.E., 2018. Health Hazards Associated with Arthropod Infestation of Stored Products. Annual review of entomology 63, 553-573.

Jian, F., 2019. Influences of Stored Product Insect Movements on Integrated Pest Management Decisions. Insects 10.

Mankin, R.W., Hodges, R.D., Nagle, H.T., Schal, C., Pereira, R.M., Koehler, P.G., 2010. Acoustic indicators for targeted detection of stored product and urban insect pests by inexpensive infrared, acoustic, and vibrational detection of movement. Journal of economic entomology 103, 1636-1646.

Min, X.J., Hickey, D.A., 2007. DNA barcodes provide a quick preview of mitochondrial genome composition. PloS one 2, e325.

Ngom, D., Fauconnier, M.L., Malumba, P., Dia, C., Thiaw, C., Sembene, M., 2020. Varietal susceptibility of maize to larger grain borer, Prostephanus truncatus (Horn) (Coleoptera;

Bostrichidae), based on grain physicochemical parameters. PloS one 15, e0232164.

Nowaczyk, K., Obrepalska-Steplowska, A., Gawlak, M., Throne, J.E., Olejarski, P., Nawrot, J., 2009. Molecular techniques for detection of Tribolium confusum infestations in stored products. Journal of economic entomology 102, 1691-1695.

Perez-Mendoza, J., Throne, J.E., Maghirang, E.B., Dowell, F.E., Baker, J.E., 2005. Insect fragments in flour: relationship to lesser grain borer (Coleoptera: Bostrichidae) infestation level in wheat and rapid detection using near-infrared spectroscopy. Journal of economic entomology 98, 2282-2291. 
Proctor, D., 1994. Grain storage techniques: evolution and trends in developing countries FAO agricultural services bulletin 109.

Rajashekar, Y., Gunasekaran, N., Shivanandappa, T., 2010. Insecticidal activity of the root extract of Decalepis hamiltonii against stored-product insect pests and its application in grain protection. Journal of food science and technology 47, 310-314.

Shi, W., Jiao, K., Liang, Y., Wang, F., 2016. Corrigendum to "Efficient detection of internal infestation in wheat based on biophotonics" [J. Photochem. Photobiol., B 155 (February 2016) 137-143]. Journal of photochemistry and photobiology. B, Biology 160, 408.

Toews, M.D., Pearson, T.C., Campbell, J.F., 2006. Imaging and automated detection of Sitophilus oryzae (Coleoptera: Curculionidae) pupae in hard red winter wheat. Journal of economic entomology $99,583-592$.
Virgilio, M., Jordaens, K., Breman, F.C., Backeljau, T., De Meyer, M., 2012. Identifying insects with incomplete DNA barcode libraries, African fruit flies (Diptera: Tephritidae) as a test case. PloS one 7, e31581.

Waongo, A., Traore, F., Ba, M.N., Dabire-Binso, C., Murdock, L.L., Baributsa, D., Sanon, A., 2019. Effects of PICS bags on insect pests of sorghum during longterm storage in Burkina Faso. Journal of stored products research 83, 261-266.

Wehling, R.L., Wetzel, D.L., Pedersen, J.R., 1984. Stored wheat insect infestation related to uric acid as determined by liquid chromatography. Journal - Association of Official Analytical Chemists 67, 644-647.

Wilson, J.A., Postlethwaite, J., Pearce, J.D., Leach, G., Lye, G.J., Shamlou, P.A., 2003. Vibrating membrane filtration for recovery and concentration of insect killing nematodes. Biotechnology and bioengineering 83, 235-240. 